\title{
A TRAMA DA CRITICA DEMOCRÁTICA: DA PARTICIPAÇÃO À REPRESENTAÇÃO E À ACCOUNTABILITY
}

\section{ADRIAN GURZA LAVALLE \\ ERNESTO ISUNZA VERA}

Este artigo atenta para deslocamentos conceituais ocorridos entre "representação política", "participação" e "accountability" na crítica interna à democracia ao longo das últimas décadas, bem como examina sua ressignificação recíproca na definição de nova trama conceitual da crítica democrática. O conceito de accountability parece oferecer, hoje, o registro normativo para lidar com as exigências de legitimidade nas experiências de representação política extraparlamentar. Argumenta-se também, que as circunstâncias históricas que propiciaram a polaridade negativa ou capacidade crítica à "participação", no campo da teoria democrática, não apenas mudaram, mas tornaram inadequada sua especificação analítica para a compreensão das experiências de inovação democrática em curso.

Palavras-chave: Pluralização da representação, participação, accountability, crítica democrática, sociedade civil.

Recebido: 18/09/2011 Aprovado: 30/09/2011

\section{THE CONCEPTUAL WEB OF DEMOCRATIC CRITIQUE: FROM PARTICIPATION TO REPRESENTATION AND ACCOUNTABILITY}

In the last decades there has been a surprising conceptual shift between the role of three concepts - political representation, participation and accountability - in the internal criticism of democracy. This article sheds light on that shift by examining the reciprocal redefinition of meaning between those concepts and the shape of a new conceptual network for democratic critique. Nowadays, internal critique of democracy has been developed from the stand point of representation theories, which used to be traditionally related to the defense of democracy. Participatory democracy models, once the 
main stand point for criticizing democracy, either lost influence or where integrated to more sophisticated deliberative democratic models. We argue that this state of affairs is due to a conceptual worthy dissociation between representative government and political representation. This dissociation works under democratic and pluralistic assumptions, thus, it is sensible to legitimacy challenges faced by extra-parliamentary political representation. In this scenario, accountability appears as a normative concept useful for dealing with those challenges. We argue as well that the democratic critical leverage of the concept of participation relied on historical circumstances that are not longer in place, rendering standard definitions of participation inaccurate for the understanding of ongoing experiences of democratic innovation.

Keywords: Pluralisation of representation, participation, accountability, democratic critique, civil society. 


\title{
A TRAMA DA CRÍTICA DEMOCRÁTICA: DA PARTICIPAÇÃO À REPRESENTAÇÃO E À ACCOUNTABILITY
}

Adrian Gurza Lavalle Ernesto Isunza Vera

\author{
Se a filosofia começa com o espanto [wonder], \\ uma discussão sobre o conceito de representação teria um \\ começo melhor se desse ao leitor algo para se espantar \\ Hanna Fenichel Pitkin ( 1967).
}

No primeiro capítulo de seu trabalho seminal sobre o conceito de representação, Hanna Pitkin (1967) formulou uma tese duplamente oportuna para pensar a crescente atenção recebida por conceitos como accountability (ou prestação de contas) e controle social, atenção esta que superpôs claramente um sobre o outro, embora não sejam conceitos idênticos, e que se multiplicou em literaturas provenientes de campos de conhecimento tão diferentes quanto negócios corporativos, estudos do desenvolvimento, políticas públicas e governança, terceiro setor e sociedade civil, globalização e, é claro, o campo vasto da teoria democrática - inclusive o das teorias da representação. Nesse capítulo, a filósofa examina as teorias da autorização que justificam e definem a representação graças à existência de um expediente inicial de consentimento popular (especialmente sua primeira e 
canônica versão elaborada por Hobbes), e conclui um capítulo depois com uma crítica acre às teorias da representação como accountability.

A tese defendida é simples e persuasiva: as teorias centradas na ideia de accountability surgem do inconformismo diante das teorias da autorização, procurando tornar mais exigente o conceito de representação ao denunciar as insuficiências de um ato de consentimento único e introduzir a necessidade de controles e sanções contínuas sobre os representantes. Curiosamente, a crítica de Pitkin às teorias de accountability obedece a motivos semelhantes: se as teorias da autorização são formalistas e parciais, dado que os problemas substantivos ou de qualidade da representação - quem ou o que deve ser representado, por qual tipo de representante ou de representação, mediante que comportamentos ou ações não são solucionáveis pela simples presença de regras e instituições de autorização, aquelas centradas na accountability são 96 igualmente formalistas e parciais, uma vez que apenas enfatizam outras regras e instituições, agora dedicadas ao controle (Pitkin, 1967, pp. 58-59). Por outras palavras, as teorias da representação como accountability nada teriam a dizer a respeito da substância ou conteúdo da representação.

A posição de Pitkin é duplamente oportuna para o debate em curso sobre a pluralização da representação política nas democracias, quer dizer, sobre os alcances do governo representativo centrado na representação eleitoral e sobre a diversificação dos atores, funções e instituições da representação política de índole extraparlamentar ${ }^{1}$. Primeiro, e em inflexão assaz surpreendente, parte da crítica interna

\footnotetext{
${ }^{1}$ O diagnóstico de reconfiguração do governo representativo foi magistralmente desenvolvido por Manin (1997). Paralelamente, diversos autores têm apontado para um processo mais amplo de pluralização das formas de representação política e dos limites da representação eleitoral (Törnquist, Webstere e Stokke, 2010; Urbinati e Warren, 2007; Castiglione e Warren, 2006; Gurza Lavalle, Houtzager e Castello, 2005; Novaro, 1995, 2000; Abal, 1996, 2004). Cumpre mencionar que o debate argentino, nesse terreno, foi pioneiro, como atestado pelas datas de publicação dos dois últimos autores.
} 
à democracia tem sido desenvolvida, nos últimos anos, do flanco das teorias da representação, ou seja, justamente de um ângulo que, no âmago da teoria democrática, costumava operar como flanco de defesa. De fato, durante boa parte do século XX, as formulações teóricas da representação e as instituições do governo representativo permaneceram fundidas ao ponto de inibir o desenvolvimento da teoria política. No seu momento, Pitkin se propôs a realizar um exercício meticuloso de clarificação conceitual - e o fez com primor. Em consonância com tal propósito, inexiste qualquer crítica ao governo representativo ou a formas de representação política substantivas (acting for) no seu livro. As críticas vieram depois, em artigos e capítulos de livros menos influentes que progressivamente elevaram o tom de denúncia sobre os riscos de alienação envolvidos na representação, opondo a eles o valor da participação como princípio vital da democracia (Pitkin e Shumer, 1982; Pitkin, 2006 [1989], 2004). Assim, a evolução do campo da teoria democrática parece ter invertido a trajetória da filósofa: hoje um flanco inovador de crítica opera no registro da representação, enquanto os modelos participativos perderam influência ou foram absorvidos pelos modelos mais sofisticados da democracia deliberativa.

Em segundo lugar, se o cruzamento em direções apostas da trajetória intelectual da filósofa e do campo da teoria democrática encerra certa ironia, ele atinge contornos paradoxais quando se repara que a crítica interna à democracia do flanco da representação parece ter encontrado seu fulcro normativo no desideratum da accountability e, do ponto de vista teórico, na conexão entre esse último conceito e o de representação. Isto é, justamente na relação que Pitkin parece ter reputado como politicamente estéril ou incapaz de alicerçar uma concepção substantiva da representação política pelo seu caráter meramente formal. Não se trata de um movimento exclusivo do debate em andamento no cam- 
po das teorias da representação, antes, há sintonia entre as estratégias analíticas nesse campo e a centralidade dos controles democráticos no espírito do tempo. A vertiginosa difusão da linguagem do controle sobre as instituições políticas é eloquente: fala-se de governança participativa, governança democrática e boa governança; de controles democráticos, direito à informação e transparência; em accountability ou, de modo mais preciso, de accountabilities - horizontal, vertical, corporativa, inversa, retrospectiva, prospectiva, eleitoral, social e societal, para citar apenas algumas das suas expressões usuais ${ }^{2}$. Assim, aparentemente, não apenas as trajetórias da filósofa e do campo seriam invertidas, como também a tônica dessa inversão estaria a procurar fundamentos onde, segundo Pitkin - autora do livro mais influente de representação no século XX - nada haveria de se encontrar.

Se o começo para o afazer da teoria é o espanto, confor98 me aconselhado na epígrafe, nada melhor do que utilizar o cruzamento de trajetórias da autora da própria epígrafe, cujo trabalho é referência canônica das teorias da representação, para se maravilhar com os deslocamentos da representação política, da accountability e da participação na crítica interna à democracia - deslocamentos, por sinal, ocorridos nas últimas décadas. Na crítica interna à democracia, há hoje uma nova trama conceitual em que não apenas os conceitos de representação e participação, tradicionalmente alinhados em coordenadas opostas, mudaram de posição e, no processo, ressignificaram-se de modo recíproco, mas outros conceitos outrora aparentemente anódinos para a crítica - como accountability e termos correlatos - ganharam centralidade. É claro que a trama conceitual da crítica contemporânea é não apenas mais ampla, mas inclui redefini-

\footnotetext{
${ }^{2}$ Para um balanço das diferentes modalidades de accountability e sua evolução na literatura, ver Gurza Lavalle e Isunza (2010).
} 
ções de envergadura graças aos desenvolvimentos das teorias deliberativas (Gutmann, 1995; Gutmann e Thompson, 2004; Habermas 1993), também incorporadas de modo profícuo na construção de teorias no campo da representação - como atestado pelos trabalhos de autores influentes no campo como Manin (1997), Urbinati (2006a, 2006b) e Young (2006 [2002]). Também no terreno da pesquisa empírica e da teoria positiva é possível identificar outros flancos de revisão e crítica, como aquele que passou a tematizar e aferir a qualidade da democracia (Diamond e Morlino, 2005).

Aqui nos ocupa apenas o deslocamento e redefinição de três termos que ora ocuparam posições polares na trama da crítica democrática - participação e representação -, ora costumaram guardar pouca ou nenhuma interconexão - participação e accountability - ou guardaram relação conceitual estreita em termos que acabaram por se tornar estreitos à luz de transformações recentes na representação política - representação e accountability. A escolha não é fortuita, o debate no Brasil ganhou densidade pari passu ao debate internacional por motivações endógenas, a saber, a diversidade e grau de institucionalização de experiências de inovação democrática implantadas a partir do final dos anos 1980 contra o pano de fundo de um ideário participativo fortemente arraigado nos atores sociais de origem popular e na esquerda acadêmica. O deslocamento, como seria de se esperar, gerou estranhamento. Mais: enquanto a crítica à democracia do flanco da representação aparece, no debate internacional, como empreendimento da teoria democrática atrelado a referentes empíricos experimentais e relativamente excepcionais - por exemplo, a Assembleia dos Cidadãos da Colúmbia Britânica (Warren, 2008) -, no Brasil, o debate ocorre dentro de um campo amplo de pesquisa empírica a respeito das novas instâncias de representação e da incidência social sobre políticas públicas em que confluem pesquisadores de movimentos sociais, da demo- 
cracia participativa, da sociedade civil, de políticas públicas, de controles democráticos e de pluralização da representação ${ }^{3}$. Essa convergência vem delineando agendas inovadoras de pesquisa empírica e fortemente conectadas com a teoria democrática, sem paralelo no debate internacional.

Neste artigo desenvolvemos dois argumentos inter-relacionados que contribuem para compreender a nova trama da crítica democrática, na qual a participação e a representação perderam suas posições reciprocamente polares. Primeiro, argumenta-se que tal estado de coisas obedece a uma salutar dissociação conceitual entre governo representativo e representação política, operada em registro pluralista e democrático - sensível, por conseguinte, a exigências de legitimidade. Em contexto de reconfiguração do governo representativo, a dissociação é animada por processos em curso de pluralização da representação política, quer dizer, do crescimento de modalidades extraparlamen100 tares de representação formal e informal. Nesse quadro, a accountability aparece hoje como uma perspectiva teórica que permite elaborar respostas aos desafios da legitimidade das novas modalidades de representação política, contornando o impasse da autorização como fonte de legitimidade. Assim, a reforma do pensamento é um movimento paralelo à própria reforma da democracia.

Segundo, a participação, ora como categoria teórica do campo da teoria democrática, ora como categoria prática dos atores sociais, consubstanciou a crítica interna à democracia na segunda metade do século XX. A força da ideia de participação foi nutrida por duas ordens de fatores. No plano analítico, foram cruciais tanto sua superposição com valores fundamentais da democracia - como autodeter-

\footnotetext{
${ }^{3}$ A produção nessas literaturas é farta, mesmo se tratando de assunto recente como a pluralização da representação. Ver, por exemplo, Raichelis (2000), Pinto (2004), Miguel (2005), Gurza Lavalle, Houtzager e Castello (2006a, 2006b), Lüchmann (2007, 2008), Avritzer (2007), Almeida (2010), Pogrebinschi e Santos (2010).
} 
minação e igualdade política - quanto seu baixo grau de especificação analítica, o que permitiu torná-la depositária de expectativas normativas de índole diversa (psicológicas, pedagógicas, distributivas, emancipatórias, de eficiência, entre outras). No plano histórico, o contexto da Guerra Fria impôs severas restrições às tentativas de desenvolver críticas internas e teorias substantivas da democracia. Nesse contexto, e mediante uma ressignificação que depurou a ideia da participação das conotações negativas herdadas do fascismo, os modelos participativos acabaram por assumir uma posição polar. O fim da Guerra Fria com os processos de democratização dos últimos lustros do século XX ocorridos na América, bem como as inovações institucionais no terreno da pluralização da representação, configuraram o cenário em que operou a redefinição do papel da participação dentro da trama da crítica democrática.

O roteiro da exposição procede de modo inverso, isto é, primeiro examina o papel da participação na crítica democrática, depois aborda o deslocamento da participação ou a perda da sua posição polar no campo da teoria democrática, e finaliza examinando as mudanças correspondentes ocorridas na representação. $\mathrm{O}$ artigo conclui com breve comentário a respeito do cruzamento das trajetórias do campo e do pensamento de Pitkin.

\section{Participação e crítica democrática ${ }^{4}$}

"Participação" é, a um só tempo, categoria nativa da prática política de atores sociais, categoria teórica da teoria democrática com pesos variáveis segundo as vertentes teóricas e os autores, e procedimento institucionalizado com funções delimitadas por leis e disposições regimentais. A

\footnotetext{
${ }^{4}$ Parte desta seção retoma e explora argumentos formulados muito embrionariamente em Gurza Lavalle [no prelo] a propósito do volume organizado por Roberto Pires [no prelo] para avançar uma agenda de pesquisa destinada a examinar a efetividade das instituições participativas no Brasil.
} 
multidimensionalidade ou polissemia dos sentidos práticos, teóricos e institucionais torna a participação um conceito fugidio, e as tentativas de definir seu valor ou seus efeitos, escorregadias. Não apenas em decorrência da diversidade de expectativas nela depositadas e de que a aferição de efeitos é operação sabidamente complexa, mas devido ao fato de sequer existirem consensos quanto aos efeitos esperáveis da participação, ou, pior, quanto à relevância de avaliá-la por seus efeitos. Afinal, ponderar o valor da participação pela sua utilidade equivale a desvalorizá-la ou torná-la secundária em relação ao efeito almejado.

Seja como for, há superposição entre certos valores tradicionalmente associados à participação e dois princípios fundamentais da democracia, a saber, autodeterminação e igualdade política ${ }^{5}$. Ambos os princípios se pressupõem reciprocamente, pois o reconhecimento do direito do demos de decidir sobre a organização e destino da polity, garan102 tindo igual tratamento à expressão dos interesses de seus membros (igualdade), supõe que os cidadãos são primordialmente sujeitos morais, isto é, indivíduos com plena capacidade de formular suas próprias concepções do bem, de escolher moralmente e de se submeter às consequências dessas decisões (autodeterminação). Graças à conexão entre igualdade política e autodeterminação, é possível investir no valor da participação para a democracia firmando a afinidade intrínseca daquela com a soberania popular. Nesse registro, Carole Pateman (1992 [1970]) recorre a Rousseau promovendo-o à situação de clássico da participação - distinção sem dúvida controversa (Garsten, 2009) -, ou Paul Hirst (1994) argumenta a favor de o Estado conceder soberania às associações como expediente de autodeterminação cidadã. Assim especificada, em função de conexões

\footnotetext{
${ }^{5}$ Embora a participação seja associada amiúde à ideia de inclusão, tal conexão não apenas é controversa, mas incorreta em mais de um aspecto. A respeito dessas incorreções, ver Urbinati (2006a) e Plotke (1997).
} 
plausíveis, a participação acaba por trazer consigo uma carga democrática radical, quer dizer, uma conexão intrínseca com a raiz da democracia.

A ascensão da participação na teoria democrática como ideia força capaz de ancorar um modelo alternativo de democracia, nutriu-se das superposições axiológicas recém-apontadas, mas sua exploração teórica e promoção ao centro da crítica democrática não foi mera decorrência de possibilidades lógicas confinadas no mundo da teoria. O contexto da Guerra Fria impôs sérios constrangimentos ao afazer da teoria política que contribuem para entender tanto as feições minimalistas - por vezes, acanhadas - da definição de democracia, quanto o fato de a participação ter se tornado o aríete da crítica interna à democracia. David Plotke (1997) formulou com agudeza os termos dessa equação. De um lado, o registro dominante da teoria democrática centrou-se nos procedimentos da escolha de governantes e na liberdade como valor fundamental, se esquivando de qualquer dimensão substantiva que pudesse conduzir o debate ao terreno dos resultados e do valor da igualdade - terreno adverso em que as conquistas distributivas do mundo comunista pesavam como argumentos contundentes. De outro lado, a crítica interna à democracia encontrava-se na posição desconfortável de ensejar o "fogo amigo", quer dizer, de questionar e elaborar conceitualmente a insatisfação com a democracia, contornando o risco de ser reputada como crítica externa, ou não democrática, filhada às "fileiras do inimigo".

Embora animada pelo clima de efervescência política dos anos 1960, a ênfase na participação como ponto de partida da crítica interna foi uma opção nada trivial no marco da história política da primeira metade do século XX. Porque passível de ser reconduzida às suas origens em autores "insupeitos" da filosofia política moderna, a crítica participacionista podia esgrimir questionamentos legítimos ou internos à tradição democrática - tal e como sustentado emble- 
maticamente por Pateman (1992 [1970]). Porém, o valor da participação distava de ser pacífico: os fascismos e o colapso traumático da república de Weimar multiplicaram os temores perante o "irracionalismo das massas" - para dizê-lo com expressão coeva. Basta lembrar que, após o fim da Segunda Guerra Mundial, a Constituição da Alemanha Ocidental expurgou todos os dispositivos de participação popular da velha Constituição (Held, 1987). Pateman (1992 [1970], pp. 10-11) denunciou os efeitos adversos desse diagnóstico a respeito do caprichoso comportamento das massas "ignaras" sob o curioso nome de "desenvolvimento da sociologia política”. Independente do mérito teórico dessa empreitada, certamente sensível aos novos tempos da crítica contracultural dos movimentos sociais, é fato que crítica participacionista adquiriu influência e, durante quase duas décadas - dos anos 1970 a 1980 -, foi entronizada como o modelo alternativo de democracia perante o modelo liberal (Pateman, 1041992 [1970], McPherson, 1991 [1977], Barber, 2003 [1984]).

Nessa posição polar de modelo alternativo aos chamados "modelo liberal", "modelo minimalista" ou "modelo procedimental”, e embora nem sempre pelo seu conteúdo explícito, os modelos participativos acabaram se tornando antitéticos dos componentes tradicionalmente associados à democracia liberal - notadamente a representação - e, a um só tempo, depositários de expectativas normativas as mais variadas, cuja realização tornar-se-ia possível como efeito decorrente da própria participação. No tom engajado da sua proposta de democracia forte, Barber (2003 [1984], p. 132) formulou emblematicamente essa oposição ao banir a representação política das práticas dignas do nome democracia. Conforme sintetizado no seu prefácio à primeira edição:

Os dispositivos principais mediante os quais a teoria liberal consegue garantir a liberdade enquanto assegura a democracia - [...] sobretudo a representação - revelaram que não 
asseguram a democracia e sequer garantem a liberdade.

Representação destrói a participação e a cidadania mesmo se serve à accountability e aos direitos privados. Representação democrática é um oximoro paradoxal produzido por nossa linguagem política; sua prática falha e confusa tornam isso ainda mais óbvio" (Barber 2003 [1984], p. xxxiv).

A rigor, o teor antitético dos modelos participacionistas em relação à representação não derivou de uma oposição homogênea e explícita expressa na literatura. No seu opúsculo sobre a democracia liberal e sua época, Macpherson não apenas entende o modelo participativo como um desdobramento possível da democracia liberal, mas defende um modelo de conselhos em que a participação deveria ocorrer na base de uma estrutura piramidal cujos patamares superiores suporiam de modo incontornável a agregação mediante expedientes de representação (McPherson, 1991 [1977], pp. 130-131). Mais: a revalorização da participação não implicava, para Pateman, abrogar a representação e sequer postular sua irrelevância, pois o governo representativo

[...] é um aspecto importante da teoria democrática; seria absurdo tentar negá-lo [...]. Contudo, deve-se notar que a teoria do governo representativo não representa toda a teoria democrática [...] nem todos os autores que gostariam de ser chamados de teóricos "clássicos da democracia" adotaram o mesmo ponto de vista a propósito do papel da participação (Pateman, 1993 [1970], pp. 32-33).

A participação local, e especificamente na fábrica, era sem dúvida mais significativa e democrática - genuinamente democrática até -, mas não supunha o cancelamento da democracia eleitoral.

Porém, formulações dualistas à la Barber e o contexto de polarização, que tornou os modelos participacionistas as 
principais referências da crítica democrática, fizeram com que a ideia de participação fosse recebida e apropriada em registro antirrepresentativo. Não é de se estranhar que no painel organizado na International Political Science Association (IPSA), a propósito do quadragésimo aniversário da obra seminal de Pitkin ${ }^{6}$, Anne Phillips (2005, p. 3) salientasse a afinidade entre a virada para a sociedade civil dos democratas radicais e sua ênfase na participação perante a inutilidade da representação e das tentativas de reformar suas instituições. Mais incisivo foi o diagnóstico de Mark Warren, que ao resenhar os acontecimentos das últimas décadas do século XX concluiu:

Acredito ser justo dizer que, entre democratas progressistas, esses desenvolvimentos [das últimas décadas] marginalizaram a linguagem da representação em favor da linguagem da democracia participativa [...]. A representação se tornou o primo pobre - por assim dizer - da linguagem aparentemente mais rica da participação democrática (Warren, 2005, p. 1).

Em virtude da sua posição polar, expectativas normativas de índoles as mais variadas gravitaram para a participação ao ponto de produzirem efeitos de sinonímia. A participação não apenas foi considerada como um valor em si, visto as superposições axiológicas permitirem considerá-la veículo por excelência da autodeterminação e da igualdade política, como também lhe foram atribuídos implícita ou explicitamente efeitos desejáveis de caráter pedagógico, psicológico, econômico e funcional, de integração e de racionalização ou controle social do poder. A educação foi resposta comum do pensamento republicano para a formação

\footnotetext{
${ }^{6}$ O nome do painel foi "Mobilizando a representação quarenta anos depois de Pitkin".
} 
das virtudes necessárias ao cabal exercício da cidadania. Os modelos participacionistas associaram-se à tradição republicana ao propor a participação como escola da cidadania, capaz de cultivar o civismo e de elevar o egoísmo à compreensão do bem público ${ }^{7}$. Afinal, "A principal função da participação na teoria democrática participativa é [...] educativa; educativa no mais amplo sentido da palavra, tanto no aspecto psicológico quanto na aquisição prática de habilidades e procedimentos democráticos" (Pateman, 1993 [1970], pp. 60-61). Os efeitos pedagógicos remetem tanto à socialização e a construção do homem público quanto aos efeitos mais propriamente psicológicos que dizem respeito à autoconfiança e à autopercepção do senso de eficácia do indivíduo. A combinação de ambos os efeitos positivos seria capaz de deflagrar círculos virtuosos em que a participação gera mais participação - daí o fato de a teoria democrática participativa ter sido caracterizada, contra analistas céticos, como modelo autossustentado (Pateman, 1993 [1970], pp. 62). O engajamento participativo também foi associado a efeitos de integração, pois incrementaria o senso de pertença do cidadão à sua sociedade, não apenas fortalecendo a formação de identidades políticas amplas, mas contribuindo para a legitimação das instituições políticas. Traço comum aos efeitos psicológicos, pedagógicos e de integração é sua natureza não estritamente voluntária, mas também gravitaram para a participação efeitos agregados em maior ou menor medida intencionais, abrindo terreno para a defesa da participação como expediente para a indução de resultados nas instituições políticas - diferentes dos efeitos sobre os participantes. Assim, associa-se à participação a capacidade de gerar efeitos distributivos quando realizada no marco de instituições incumbidas de orientar as políticas e as

7 Seja dito de passagem que tal conexão não é obvia nem pacífica, pois linhagem republicana e seu princípio de excelência não são facilmente conciliáveis com o princípio plebeísta da ampliação da participação (Araujo, 2000). 
prioridades de alocação de recursos públicos. Os efeitos distributivos, todavia, são apenas uma subcategoria da relação mais geral entre participação e a capacidade da sociedade de influir nas políticas públicas e, em termos mais gerais e ambiciosos, de racionalizar o exercício do poder político (Fung e Wright, 2003; Santos, 2002) ${ }^{8}$.

Em suma, pelas afinidades axiológicas com princípios fundamentais da democracia e pelas circunstâncias históricas que restringiram o espaço para a crítica democrática durante o contexto da Guerra Fria, a reabilitação da participação do halo irracionalista que lhe herdaram os fascismos acabou por torná-la um desideratum político capaz de comportar expectativas normativas variadas e de exprimi-las com uma semântica intuitivamente simples e persuasiva porque, aparentemente, autoevidente. Esse caráter intuitivo devera mais à rarefação de um ambiente político hermético à experimentação democrática do que à precisão e à clareza das 108 ideias. Sem dúvida, a participação é defensável como um princípio moral; mas qualquer tentativa de explicitar os mecanismos pressupostos para a geração das consequências esperadas mostraria a presença de trade offs entre efeitos desejáveis, desaconselhando cair na velha tentação de acreditar que todas as "coisas boas vão juntas"9. Nos últimos

\footnotetext{
8 No elenco recém-arrolado apenas foram considerados efeitos sobre os participantes e sobre as instituições políticas, formulados no registro da teoria democrática, mas na literatura de sociedade civil também tem sido postulada a produção de bens públicos, quer dizer, de benefícios disponíveis para todos os indivíduos de uma comunidade, inclusive aqueles não envolvidos nas práticas de participação responsáveis por gerar tais benefícios. A formulação contemporânea mais conhecida conceitua esses efeitos em termos de capital social (Putnam, 2002), entendido como bem coletivo subproduto da participação orientada a determinados propósitos coletivos particulares. Assim, a participação incrementaria os estoques de confiança disponíveis em uma determinada coletividade, viabilizando a cooperação e a criação de respostas coletivas a problemas comuns (Putnam, 2002; Ostrom, Ahn e Olizares 2003). Por motivos similares, a participação fortaleceria as associações ou a sociedade civil e, embora por caminhos pouco especificados, estimularia o bom governo.

9 Como mostrado com competência por Cunill (1997, p. 71-195), a participação, mesmo quando verificada, não implica garantia alguma quanto à realização das
} 
anos, a participação e a representação perderam suas posições polares e, com isso, passaram por um processo de ressignificação recíproca, fazendo com que a primeira perdesse seu caráter autoevidente e, a segunda, sua identidade naturalizada identificada com o governo representativo.

\section{A perda de polaridade da participação... e 0 estranhamento ${ }^{10}$}

As últimas décadas do século XX, marcadas pelos ciclos das transições políticas na América Latina e das "revoluções de veludo" na Europa do Leste - e, consequentemente, pelo fim da Guerra Fria - trouxeram consigo mudanças no espírito do tempo no que se refere ao valor da democracia e na própria teoria e instituições democráticas. Se, de um lado, o valor da democracia como conjunto de regras formais para a sucessão e autorização de governantes alcançou consensos sem precedentes, de outro, a subsequente expansão do número de novas democracias e a ausência de "inimigos" externos que reforçassem posturas defensivas, propiciaram o alargamento da crítica democrática a emergência de agendas dirigidas a indagar e questionar a qualidade das velhas e novas democracias. No contexto da Guerra Fria, quando o desafio era defender, restaurar e expandir a democracia, a concepção liberal procedimental mostrou-se, em maior ou menor grau, consistente no plano analítico e convincente no plano político - minimalismo procedimental e o valor da liberdade política, respectivamente (Plotke, 1997). Con-

virtualidades positivas esperadas. Curiosamente, as literaturas que de modo mais sistemático têm enfrentado o desafio de explicitar e verificar os efeitos atribuíveis à participação, assim como identificar os mecanismos responsáveis pela produção desses efeitos, inscrevem-se em outras agendas de trabalho diferentes às da democracia participativa ou do aprofundamento da democracia. Notoriamente, a densa produção dos modelos do status socioeconômico, do voluntarismo cívico e da mobilização política. Ver Verba, Schlozman, Lehman e Brady (1995); Rosenstone e Hansen (1993); Verba, Nie e Kim (1978).

${ }^{10}$ Esta seção reformula de modo sintético e introduz alterações substantivas à proposta de esclarecimento conceitual desenvolvida em Gurza Lavalle e Isunza (2010). 
tudo, uma vez instauradas as novas democracias, a mesma concepção perdeu seu mordente crítico e se tornou insuficiente, mas sem deixar de ser irrenunciável.

No plano teórico, nos termos da influente formulação de Gutmann (1995), essa concepção procedimental induzia ao conformismo no novo contexto e, por isso, era desejável empreender novos desenvolvimentos teóricos capazes, ao mesmo tempo, de preservar o núcleo liberal procedimental da democracia e de animar e dar sustentação a concepções mais exigentes com o funcionamento e com a qualidade das instituições democráticas. Afinal, não deixava de ser irônico que as acolhidas entusiastas à democracia dos países que emergiram após a decomposição da União Soviética fossem realizadas por acadêmicos e publicistas democratas que alimentavam sérias insatisfações em relação ao estado da democracia nos seus próprios países. Exemplo eloquente desse deslocamento é a emergência e rápida expansão de 110 vertentes deliberativas procedimentais de teoria democrática (Habermas, 1993, 1995; Elster, 1998; Bohmam e Rehg, 2002; Gutmann e Thompson, 2004), bem como os debates sobre a qualidade, representatividade e accountability das instituições da democracia (Schedler, Diamond e Plattner, 1999; Przeworski, Stokes e Manin, 1999; Schedler, 1999; Diamond e Morlino, 2005)

No plano da inovação democrática, registraram-se mudanças aquém e além das fronteiras institucionais do governo representativo. Já a partir dos convulsos anos 1960, nas democracias mais tradicionais do hemisfério norte foram promulgadas e/ou crescentemente utilizadas modalidades de participação cidadã direta - como o plebiscito, o referendo e a iniciativa popular - percorrendo os trilhos do governo representativo, mas diversificando e ampliando a capilaridade deste. De modo consoante, nos países da Organização para a Cooperação e Desenvolvimento Econômico (OECD) registrou-se um crescimento contínuo, 
entre os anos 1960 e 1990, nos níveis supra e infranacionais em que passaram a ocorrer eleições, na variedade de assuntos submetidos à decisão pública mediante sufrágio, bem como na frequência de eleições e no número de segundos turnos (Dalton e Gray, 2006). As mudanças institucionais associadas à perda de polaridade da participação, todavia, são posteriores e constituem fenômeno inédito e consideravelmente mais diversificado, pois as modalidades de pluralização institucional da democracia - notadamente a proliferação de canais extraparlamentares de representação formal e informal - costumam estar situadas fora das fronteiras tradicionais do governo representativo e exercer funções que não contam com antecedentes óbvios na doutrina democrática liberal.

O repertório da pluralização institucional da democracia é amplo e contempla, em contextos específicos de ambos os hemisférios, instâncias colegiadas para a definição e fiscalização de políticas, para a elaboração de prioridades no terreno do planejamento ou da atribuição de gasto público, comitês participativos em diferentes instâncias da administração pública, ombudsman, leis de transparência, instituições eleitorais de caráter civil, observatórios cidadãos, comissões de vigilância, ouvidorias, vedorias e comitês cidadãos, painéis cidadãos, jurados cidadãos, para mencionar apenas alguns casos (Ansell e Gingrich, 2006; Isunza e Gurza Lavalle, 2010). Algumas das inovações têm, inclusive, alcançado notoriedade mundial: a começar pelas Emendas Constitucionais 73 e 74 na Índia - especialmente a conhecida People's planning campaign no estado de Kerala, no sul do país (Chaudhri e Heller, 2002) -, os Conselhos Gestores de Políticas Públicas, as experiências de Orçamento Participativo (OP) e as conferências nacionais no Brasil (Tatagiba, 2002 e 2010; Lüchmann, 2007 e 2008; Avritzer e Navarro, 2003); a participação e controle cidadãos no sistema eleitoral mexicano (Alonso e Aziz, 2005; Aziz e Isunza, 
2007; Isunza, 2006a e 2006b), assim como do sistema de proteção do direito à informação pública governamental nesse país (Alonso, 2007; Ackerman Rose, 2007); o Local Government Code nas Filipinas, a Lei de Participação Popular na Bolívia e o New Localism na Inglaterra (Gaventa, 2004), a vigilância policial comunitária de Chicago, assim como a proliferação de instâncias colegiadas de participação - e representação-cidadã em toda a América Latina (Grindle, 1999; Albuquerque, 2008) - instâncias consagradas explicitamente nos textos constitucionais da maior parte dos países da região (Hevia de la Jara, 2006).

Uma peculiaridade de boa parte dessas experiências é que nelas imbricam-se práticas que tradicionalmente apareceram na teoria democrática e na linguagem dos atores - ou apareciam até pouco tempo atrás - separadas por lógicas diferentes ou mesmo opostas. De fato, como consequência dos deslocamentos animados pelas experiên112 cias de pluralização da representação, nossas concepções de participação e representação, tributárias da realidade da Guerra Fria, começaram a se tornar velhas perante a novidade do mundo ou, de modo mais preciso, perderam potência para apreender as transformações em curso. Ambas as concepções, reciprocamente conotadas pela sua polaridade, tornaram-se um obstáculo de pensamento (Bachelard, 1996) para pensar o novum inscrito na multiplicação de modalidades de representação extraparlamentar, pois, por um lado, elas dissolvem a divisão entre a defesa liberal procedimental da democracia e seus mecanismos "exclusivos" - representação por autorização e accountability como pesos e contrapesos institucionais ou como competição de caráter eleitoral pelo voto popular -, e, por outro, a crítica democrática comprometida com a democratização como participação e com o controle social do poder mediante a pressão e mobilização social de caráter extrainstitucional. Ou seja, as experiências de 
pluralização da representação diluem as fronteiras estáveis que tinham diferenciado as posições liberais e de esquerda em relação à disputa pela democracia.

A pluralização da representação implica mudanças inéditas no lócus, funções e atores da representação - no último caso, vinculando ao exercício de responsabilidades representativas atores que a teoria costumou indicar sob signo da participação (Gurza Lavalle, Houtzager, Castello, 2006a). Os canais de representação extraparlamentar são excêntricos, pois operam fora do lócus por excelência da representação no governo representativo - o Parlamento -, não raro vinculados à estrutura administrativa do Poder Executivo. Destinam-se ao desempenho de funções outras que não as legislativas: ora a definição, fiscalização e gestão de políticas públicas, ora à observação e emissão de denúncias ou recomendações sobre a conduta de corporações do poder público e de setores da política pública. Os atores que falam em nome de interesses e segmentos da população não apenas diferem na sua filiação institucional das duas instituições que, no século XX, tornaram possível a conciliação do governo representativo com a democracia de massas - sindicatos e partido políticos (Manin, 1997, Chalmers, Martin e Piester, 1997) -, mas incorporam atores outrora apenas associáveis, pelas suas feições, ao polo da participação: cidadãos qua cidadãos - não como políticos, nem como lideranças -, redes de atores sociais e movimentos, ONGs e diversas entidades de advocacy, associações comunitárias e de autoajuda, e personalidades com ampla notoriedade pública (Vieira e Runciman, 2008, pp. 49-181; Castiglione e Warren, 2006; Lüchmann, 2007; Saward, 2010; Gurza Lavalle, Acharya e Houtzager, 2005).

A perda de posição polar da participação veio acompanhada de um processo de ressignificação que, como era de se esperar, causou estranhamento em contextos como o latino-americano, no qual a o ideário participativo esteve associado 
às lutas pela democratização e aos reclamos de atores coletivos que transbordavam as estruturas de controle corporativo do Estado $^{11}$. O estranhamento é compreensível: a participação perdeu nitidez semântica e embaralharam-se seus usos analíticos com termos outrora restritos à linguagem da representação ou francamente desinteressantes se julgados do ponto de vista da carga normativa da própria participação. Assim, as experiências de pluralização institucional da democracia e os atores sociais a ocupá-las começaram a ser pensados em registros analíticos "mistos", articulando a linguagem da participação com, por exemplo, a linguagem da accountability social. Nessa direção, "sociedade civil", "movimentos sociais" e "cidadãos", todos eles sujeitos da "participação" - direta, deliberativa, democrática, política - tornaram-se compatíveis com "governança", "transparência", "controles democráticos", "eficiência”, "prestação de contas”, como atores da “accountability social" (Peruzzotti e Smulovitz 2002; Alnoor 114 e Weisband 2007; Houtzager, Gurza Lavalle e Yoshi 2009). É difícil não perceber que a linguagem da accountability, é claro, traz consigo sentidos sempre mais restritos que aqueles disponíveis na carga normativa associada à participação.

No contexto latino-americano e dos latino-americanistas, quiçá a primeira expressão claramente articulada - sem dúvida, a mais influente - do estranhamento causado pela perda de centralidade da participação nesse contexto seja o diagnóstico da "confluência perversa" formulado por Evelina Dagnino (2002 e 2004). Ele exprime suspicácia e desconfiança perante um mundo em que a participação e outros vocábulos como "cidadania" e "descentralização" adquiriram valor positivo para "gregos e troianos", alertando que a homonímia ocultaria divergências profundas nos proje-

\footnotetext{
${ }^{11}$ Utiliza-se a expressão ideário participativo para diferenciar os usos simbólicos práticos da participação por atores sociais dos seus usos teóricos no campo da teoria democrática. Conforme será visto logo a seguir, há diferenças genealógicas e de significado relevantes entre ambos os usos.
} 
tos políticos subjacentes (Dagnino, 2006 e 2007). A carga democratizadora associada à participação correria o risco de ser substituída pela lógica da gestão, assim como o discurso da cidadania, centrado na defesa de direitos, apareceria deslocado por uma noção de cidadania de usuários ou centrada na corresponsabilidade ${ }^{12}$. Reservas semelhantes foram manifestadas em outras latitudes, chamando a atenção sobre a disputa política de sentidos subjacente às "palavras-curinga", ou aos "passe-partout semânticos" característicos do campo dos estudos do desenvolvimento e dos circuitos internacionais de formuladores de políticas (Cornwall e Coelho, 2007) ${ }^{13}$. A sobreposição linguística ocultaria a disputa e as divergências fundamentais, ou, para dizê-lo com o trocadilho utilizado por Cornwall (2007), buzzwords acabariam se desempenhando como fuzzwords.

Porém, em boa medida, o fim da Guerra Fria subjaz à confluência semântica entre atores e literaturas oriundos de posições díspares no espectro político ${ }^{14}$. Esse conjunto de transformações extraordinárias trouxe consigo uma rajada de ar fresco tanto para a teoria democrática - hoje renovada com perguntas substantivas - quanto para o debate intelectual e para a formulação e disputa públicas de demandas distributivas por parte dos atores sociais. A emergência de plataformas semânticas compartilhadas por compreensões da realidade e forças políticas opostas permite entabular uma disputa pelo mundo em termos do significado concreto de categorias aceitas como legítimas - notoriamente cida-

\footnotetext{
${ }^{12} \mathrm{O}$ diagnóstico da confluência perversa ganhou ampla presença no debate latino-americano. Para sua reapropriação em diferentes países da região, ver, por exemplo, Contreras (2003), Ochoa (2004), Delamaza (2005); Dagnino, Olvera e Panfichi (2006) e Rocha (2007).

${ }^{13}$ Ver a edição especial de Development in Practice, editada por Cornwall (2007), e dedicada ao assunto, especialmente os trabalhos de Leal, Scoones, Batliwala e Chandhoke. ${ }^{14}$ Cumpre lembrar o papel da geopolítica mundial da Guerra Fria após a Revolução Cubana, que definiu o cenário de polarização e fez confluir os interesses da política externa norte-americana com os golpes militares no Cone Sul.
} 
dania, democracia, participação, inclusão, diretos humanos e, mais recentemente, accountability. De fato, contra o pano de fundo do fim da Guerra Fria, a confluência responde a uma dinâmica histórica mais ampla e mostra-se aberta a possibilidades virtuosas ou perversas. Emprestando a fórmula influente de Dagnino, não é descabido afirmar que as polaridades simbólicas desse período, embora ordenassem ao embate político em oposições contrastantes alinhadas sob a dualidade capitalismo versus comunismo, encerravam dualidades enganosas ao modo de uma "divergência perversa". Com efeito, durante anos, no final do segundo pós-guerra, as divergências intelectuais e demandas sociais - não necessariamente antissistêmicas - foram polarizadas e ressignificadas artificialmente para além das intenções de seus protagonistas. Exemplarmente, a reforma do socialismo foi combatida como subversão antirrevolucionária e, do outro lado, as demandas por inclusão democrática, por jus116 tiça social e participação popular foram reprimidas como sedição guiada por ideologias antipatrióticas e comunistas.

Curiosamente, a despeito de o ideário participativo derivar, no Brasil, de uma genealogia própria e diferente da participação na teoria democrática, o ponto de chegada é, em certo sentido, similar. Como categoria prática ao serviço da ação, a participação emerge mais propriamente nos anos 1960, articulada a uma visão emancipatória das camadas populares. O ideário participativo construído a partir dos anos 1960 conjugou diversos significados. A participação-popular não remetia às eleições, nem às instituições do governo representativo, e tampouco era liberal no sentido de invocar um direito que contempla o livre envolvimento da população como um todo - dos cidadãos -, independentemente das classes sociais. Na construção desse ideário, "participar" significava, em estreita conexão com a teologia da libertação, apostar na agência das camadas populares, ou, conforme os termos da época, tornar o povo ator da sua 
própria história. Ademais, a participação-popular se inscrevia em perspectiva mais ampla, preocupada com a construção de uma sociedade justa, sem exploração. O ideário participativo adquiriu novo perfil no contexto da constituinte e a participação, outrora popular, tornou-se cidadã. A participação-cidadã encarnou a progressiva liberalização política e respondeu ao desafio de incorporar e adequar o ideário participativo herdado das duas décadas anteriores, com tônica classista, às exigências de um discurso público em registro universalizante, apropriado para incidir na disputa da nova Constituição. Assim, os atores engajados com a participação popular reelaboraram seu discurso em termos de participação cidadã, e o ideário participativo adquiriu feições mais abstratas e foi consagrado, em 1988, como direito cidadão. Por fim, a regulamentação dos preceitos constitucionais em matéria de participação adotou os conselhos como expedientes institucionais para viabilizar a participação na gestão de políticas definidas como estratégicas. Ao longo da segunda metade dos anos 1990 e na década seguinte, a participação passou a ser, cada vez mais, participação-em-espaços-participativos e a literatura acadêmica migrou junto com os atores que passaram a se envolver nesses espaços. Movimento claro nessa direção foi antecipado por Dagnino (2002) e seus colaboradores ao se debruçarem sobre o papel da sociedade civil nos chamados espaços públicos, e, um ano depois, sinalizado novamente por Avritzer e Navarro (2003) e colaboradores ao se debruçarem sobre as variações do OP como caso de inovação democrática.

Concomitantemente, na literatura internacional a ideia da participação como modelo alternativo de democracia também cedeu passo à avaliação de experiências específicas - como o OP ou a descentralização do planejamento em Kerala - com o intuito duplo de diagnosticar os fatores que obstaculizam e potencializam os alcances da participação, e identificar, dentre aqueles que condicionam experiências 
bem-sucedidas, lições para a replicação de tais experiências em contextos diferentes (Heller, 2001; Fung, 2004; Fung e Wright, 2003; Santos, 2002; Thompson, 2007). Repare-se: da defesa de um modelo participativo de democracia transitou-se para o estudo de inovações institucionais bem-sucedidas e da sua capacidade de introduzir correções dentro da dinâmica mais geral do governo representativo.

\section{Representação, crítica democrática... e legitimidade}

O deslocamento do conceito de representação da sua outrora condição polar na teoria para uma posição que permite articulá-lo à crítica democrática obedece, grosso modo, a dois processos paralelos: o de reconfiguração e o de pluralização da representação - nem sempre interpretados pela literatura como interdependentes ou, pelo menos, com implicações que se interpelam reciprocamente. $\mathrm{O}$ fim dos chamados trinta anos gloriosos do segundo pós-guerra

118 desencadeou um conjunto de processos de reestruturação econômica e política, amiúde interpretado em registro altissonante sob as etiquetas "crise" e "fim" - do Estado de bem-estar, do trabalho, das ideologias etc. A representação política e, especificamente, o governo representativo, não foram exceção e sobre eles se precipitaram diagnósticos de crise - do advento de uma "democracia pós-representativa”, até (Abal Medina, 1996) -, invocando causas variadas como a perda de centralidade dos partidos de massas, mudanças de hábitos políticos dos eleitores, erosão das grandes categorias sociais atreladas ao mundo do trabalho, a crescente expansão das funções de comunicação política desempenhadas pela mídia, para mencionar apenas alguns argumentos recorrentes. Bernard Manin (1997) conferiu inteligibilidade às mudanças apontadas na literatura a partir de um diagnóstico secular de configuração institucional e reconfiguração da representação, e, a um só tempo, tornou as leituras alarmistas "sintomas desavisados” do mesmo processo. Não é o propósito 
aqui abordar o diagnóstico de Manin, já examinado alhures (Gurza Lavalle, Houtzager, Castello, 2006a), nem é prudente assumi-lo como se fosse isento de controvérsia - ver as críticas de Rosanvallon (1998) e Urbinati (2006a). Entretanto, alguns dos seus componentes mais relevantes parecem pacíficos: continuidade de feições institucionais básicas do governo representativo - voto, autonomia do representante, liberdade de formação e expressão de opinião e deliberação prévia à tomada de decisões -, e relativa descontinuidade quanto à perda de centralidade dos partidos, ao aumento da autonomia das lideranças partidárias e à importância das funções de comunicação política da mídia.

A pluralização da representação já foi descrita na seção anterior em termos de diversificação do lócus, das funções e dos atores da representação, mas suas eventuais conexões com a reconfiguração da representação e com a crítica democrática ainda carecem especificação. Em virtude da sua relevância histórica e da sua conexão umbilical com a formação do Estado-nação, a representação política no mundo moderno deveio progressivamente sinônimo de governo representativo (Pitkin, 2006; Manin, 1997). Para dizê-lo emprestando as palavras de Arditi (2005), o governo representativo hegemonizou a representação política, projetando um halo de ilegitimidade e irrelevância sobre outras formas de representação. Em que pese o pensamento de teóricos como Eric Voeglin e Karl Schmitt (Novaro, 2000), e inclusive a compreensão de Pitkin (1967, pp. 209-239) da representação política como arranjos públicos institucionalizados de larga escala que não coincidem necessariamente com o governo representativo - por exemplo, formas de representação funcional -, a posição convencional da teoria democrática fundiu representação política e governo representativo. Quando tal sinonímia é assumida ou presumida, apenas adquirem relevância mudanças e processos localizados no coração do sistema político, e a pluralização 
da representação sequer é percebida ou julgada supérflua (Manin, 1997; Przeeworski, Stokes e Manin 1999; Przeworski, 2002). Mesmo no caso de uma proposta teórica de fôlego, como a de Urbinati (2006a), de caráter crítico e dirigida a ampliar normativamente o campo das teorias da representação, a pressuposição de tal sinonímia oblitera completamente a pluralização da representação, fazendo com que a sua análise discorra inteiramente dentro das fronteiras do governo representativo. Porém, a reconfiguração da representação também deu ensejo a trabalhos orientados a mostrar as condições de possibilidade da representação política no mundo moderno, sua variação histórica e os dilemas de legitimidade endêmicos do governo representativo (Rosanvallon, 1998; Saward, 2010; Ankersmit, 2002; Novaro, 2000; Abal Medina, 2004; Vieira e Runciman, 2008). À luz desses desenvolvimentos teóricos, a pluralização da representação aparece, no mínimo, como terreno de possibilidades para a 120 representação nas sociedades contemporâneas que não usurpam o governo representativo nem conflitam de modo irreconciliável com ele.

Há outro caminho para conectar reconfiguração e a pluralização da representação, de sentido inverso, quer dizer, a partir não das mudanças associadas à reconfiguração da representação, mas do exame da pluralidade de inovações institucionais em si, cujas implicações mais relevantes, do ponto de vista da teoria democrática, apenas emergem ao olhar do observador se elaboradas analiticamente no registro da representação - e não apenas da participação - e cujo significado mais amplo é normalmente associado aos déficits de legitimidade e/ou limites das instituições do governo representativo. Essa foi a via majoritariamente percorrida pela literatura no Brasil, plausivelmente em decorrência da proliferação de experiências de inovação democrática, cuja diversidade, abrangência territorial e graus de institucionalização ao longo dos diferentes níveis de autoridade da fede- 
ração conferem ao país o caráter de um imenso laboratório para o exame da pluralização institucional da democracia. Segundo o levantamento mais confiável disponível, no ano de 2001, existiam inúmeros conselhos municipais gestores de políticas pelo Brasil afora: de saúde (5426), assistência social (5178), direitos da criança e do adolescente (4036), educação (4072), no caso das áreas definidas como estratégicas pela Constituição, mas também em outras áreas como emprego e trabalho (1886); meio ambiente (1615) e turismo (1226), para mencionar apenas alguns exemplos com cifras superiores ao milhar de casos (IBGE 2001). Além dos conselhos em nível estadual e nacional, levantamentos exaustivos no nível local revelam que, no caso de municípios como São Paulo e Guarulhos, por exemplo, há mais de trinta conselhos em Operação (Tatagiba, 2010; Gurza Lavalle, Oliveira, Serafim, Voigt, 2011). As conferências nacionais, com seus respectivos ciclos de conferências municipais, estaduais, livres e virtuais, também atingiram cifras expressivas: entre 1988 e 2009 foram realizadas oitenta, a maior parte das quais não mandatadas pelas regulações setoriais (Pogrebinschi, 2010). Por fim, a referência ao OP é, obviamente, inescapável, pela sua relevância simbólica e pela sua extraordinária difusão além das fronteiras nacionais (Oliveira, 2011). A contabilidade sobre o OP varia, mas entre 1995 e 2005 foram registradas ao redor de duzentas experiências no país (Ribeiro e Grazia, 2003; Avritzer e Wampler, 2008; Cabannes, 2006). Os números da sua difusão, todavia, são mais avultados: no ano de 2006, registraram-se 1200 municípios latino-americanos com OP e, em 2008, 100 casos na Europa (Cabannes, 2006; Sintomer, Herzberg e Röcke, 2008). No Peru, o OP tornou-se mandatório e, em 2007, encontrava-se implementado em 532 municipalidades (Hordijk, 2009).

De fato, não é exagero afirmar que a "participação" é uma feição das instituições do Estado brasileiro, isto é, transbordou o estatuto de reclamo dos atores sociais e de 
orientação política programática de governos e partidos embora preserve esse caráter duplo -, atingindo um desenvolvimento institucional sem paralelo em outros contextos. Não é de se estranhar que a literatura internacional via de regra qualifique as experiências e possíveis desdobramentos da representação extraparlamentar, bem como as ações de mediação política dos atores da sociedade civil, lançando mão do adjetivo "informais" (Castiglione e Warren, 2006; Urbinati e Warren, 2007; Peruzotti, Smulovitz, 2002). Diferentemente, no Brasil as funções exercidas por atores da sociedade civil nas instituições de representação extraparlamentar constituem representação de pleno direito - de jure-, e não apenas de fato, pela projeção de reclamos em nome de outrem. Foram olhares atentos para os chamados "espaços participativos" que, pari passu ao debate internacional, mas por motivações endógenas, problematizaram-nos como modalidades de representação extraparlamentar

122 e apontaram para o processo de pluralização da representação em curso (Pinto, 2004; Gurza Lavalle, Acharya, Houtzager, 2005; Lüchmann, 2007; Almeida 2010).

Caminho semelhante da participação à representação foi percorrido em outras latitudes, com lastro em outras referências empíricas. Nas palavras de Warren (2005, p.2):

[...] embora experimentos de participação política nunca tenham sido tão promissores, a linguagem da participação exauriu muitas das suas capacidades críticas por sobreutilização e sobre-ampliação [...] podemos injetar novas capacidades críticas na linguagem da participação repensado-a na linguagem da representação. Muitas das novas formas de participação quiçá sejam mais bem-entendidas e avaliadas como novas formas de representação [...].

Não é fortuito que Warren (2008) seja uma das referências obrigatórias no debate internacional sobre a pluralização da 
representação, precisamente um estudioso da Assembleia dos Cidadãos da Colúmbia Britânica - corpo deliberativo instituído com o intuito de emitir recomendações para a reforma do sistema eleitoral, composto de cidadãos aleatoriamente escolhidos, mantendo o controle de gênero e de distribuição etária compatíveis com sua distribuição na população. Do outro lado do Oceano Atlântico, e tendo como pano de fundo o Novo Localismo Britânico (Gaventa, 2004), e "[...] a considerável experimentação e institucionalização de formas de governança participativa na Europa”, Barnes e Skelcher (2007, p. 2) identificam que "[...] a virada participacionista nos sistemas de governança” objetiva como propósito fundamental a representação local por atores da sociedade civil. Por sua vez, examinando diversos projetos que envolvem atores e movimentos sociais nas Filipinas, na Indonésia e na Índia, Törnquist, Webster, Stokke (2010) e seus colaboradores atentam para a relevância de se pensar o papel desses atores em termos de representação e avançam um modelo para tanto.

Em suma, a representação também perdeu sua condição polar no campo da teoria democrática e, em deslocamento salutar, introduziu-se uma dissociação da relação demasiadamente estreita - quase idêntica - que manteve nesse campo com o governo representativo. Há diversas expressões dessa dissociação, a mais sintética das quais seja quiçá o fato de a "representação democrática" e a questão "o que torna a representação democrática?" terem adquirido estatuto teórico próprio em relação ao "governo representativo" e à "representação eleitoral", bem como a repostas centradas nos dois últimos (Pettit, 2010; Urbinati e Warren, 2007). Assim, Peruzotti, em artigo sobre a abordagem teórica predominante da representação na América Latina "[...] atenta para uma compreensão da representação democrática que vai além dos modelos centrados em eleições”, pois "a mediação política na esfera pública, e não as eleições, 
deveria ser tomada como traço distintivo da representação democrática" (Peruzzotti, 2006, p. 2; 15). Em outras palavras, a representação pelo sistema político tornou-se alvo de pretensões de representatividade conflitantes ("competing claims"), o que implica colocar em xeque o alinhamento automático entre Estado, parlamento, nação e formação da vontade e do juízo políticos - alinhamento que, na compreensão tradicional da representação, garantia uma espécie de legitimidade apriorística às decisões tomadas nos canais do governo representativo (Castiglione e Warren, 2006; Saward, 2010). Inclusive os circuitos da representação eleitoral ganharam não apenas problematizações e teorizações normativas (Urbinati, 2006a, Young, 2006; Williams, 1998), mas teorizações positivas ricas quanto a sua capacidade de iluminar as diversas modalidades de exercício da representação dos parlamentares ocultas sob a rubrica "representação eleitoral" (Mansbridge, 2003), e os diferen-

124 tes mecanismos institucionais externos ao ciclo eleitoral que, eventualmente, poderiam contribuir para a representatividade das instituições representativas (Przeworski, Stokes e Manin, 1999).

A perda da condição polar da representação trouxe no seu cerne duas implicações relevantes para a ressignificação da participação, a saber, a redefinição do valor da própria representação e a introdução da questão da legitimidade dentro das práticas de intermediação política dos atores da sociedade civil - práticas, por sinal, outrora pensadas em registro participativo. No primeiro caso, trata-se de resgatar a representação e o governo representativo da sua posição de sucedâneo defeituoso ou um mal necessário diante da incapacidade factual de construir formas de democracia direta (participação). Afirma-se a representação não apenas como núcleo normativo e operacional da democracia - "democracia é representação", nos termos de Urbinati (2000 e 2006a) ou de Plotke (1997) -, mas também 
como terreno privilegiado de experimentação e inovação para ampliar e aprimorar a democracia (Miguel, 2005; Castiglione e Warren, 2006; Gurza Lavalle, Houtzager e Castello, 2006a; Urbinati e Warren, 2007; Törnquist, Webster e Stokke, 2010; Gurza Lavalle e Isunza, 2010).

$\mathrm{O}$ argumento mais recorrente da teoria democrática para justificar a representação foi tradicionalmente de escala, fosse ela populacional ou geográfica. Enquanto a democracia se aviria bem com sociedades de pequenas dimensões, a representação seria a única opção disponível para sociedades populosas de territórios vastos. Nesse sentido, a representação foi justificada como uma fatalidade, uma opção second best incontornável à qual se recorre porque não mais é possível a democracia "genuína", quer dizer, direta.

Os desenvolvimentos notáveis ocorridos no campo das teorias da representação nas últimas duas décadas redefiniram nossa compreensão do governo representativo como forma de governo com linhagem e objetivos próprios, cuja escolha foi informada pelas suas virtudes (Manin, 1997; Urbinati, 2006b; Plotke, 1997). Existem discrepâncias sobre as virtudes almejadas pelos pais fundadores do governo representativo, bem como a respeito dos termos pertinentes para uma defesa contemporânea lastreada em virtudes adquiríveis ou adquiridas ao longo da massificação da democracia. Aqui há espaço apenas para mencionar as linhas de argumentação normativas que mais claramente interpelam o significado da participação. Primeiro, é possível definir representação como oposta à exclusão e não à participação, cujo antônimo é a apatia ou, dependendo das referências analíticas adotadas, talvez a abstenção (Plotke, 1997). O desenho institucional das formas de representação extraparlamentar pode combinar modalidades de inclusão sem participação, vincular essas modalidades com formas de presença direta ou, inclusive, vinculá-las definindo incentivos para desestimular a apatia (Lüchmann 2007, 
2008). Segundo, se a virtude principal da representação for a inclusão, tal capacidade de incluir é magnificada pela sua lógica de política indireta (indirectedness), que permite tanto incorporar discursos quanto multiplicar os lugares de fala dissonantes em relação a discursos com pretensões de enunciação da vontade popular (Urbinati, 2006; Garsten, 2010). De fato, os efeitos inclusivos do caráter indireto da representação revelam-se distintivos da atuação dos atores da sociedade civil que ocupam os espaços abertos pela pluralização da representação (Pinto, 2004; Almeida, 2010). Terceiro, se a participação é a afirmação de uma vontade, pronunciada em primeira pessoa do singular, e, sob o princípio de maioria, seu resultado é a imposição de uma vontade sobre outra, a representação, por sua vez, visa a incluir discursos relevantes, inclusive aqueles minoritários (Urbinati, 2006a). Por fim, a política indireta é uma força politizadora da sociedade, pois falar em nome dos interesses de alguém 126 induz a formulação de discursos e de pretensões de representatividades aceitáveis na esfera pública (Urbinati, 2006a; Gurza Lavalle e Castello, 2006b e 2008).

A pluralização de práticas, instâncias e atores da representação, assim como a diversificação de grupos sociais com exigências e direito de representação desafiam e são desafiados pelo modelo da representação eleitoral por dois motivos principais, passíveis de interpretação como sendo conducentes a déficits de legitimidade: a ausência de autorização e a inevitável ambiguidade no que se refere aos grupos sociais eventualmente representados. De fato, não é a primeira vez que a centralidade da representação eleitoral nas democracias liberais é colocada em xeque: as críticas neocorporativistas fizeram-no, mas opuseram à representação liberal um modelo antipluralista e monopólico, dependente das ideias de interesse e de estrutura das classes sociais (Schmitter, 1974). Hoje, a dissociação conceitual entre governo representativo e representação política opera em registro 
pluralista e democrático - sensível, portanto, a exigências de representatividade sempre espinhosas visto que introduzem questionamentos sobre legitimidade democrática da atuação atores que, até recentemente, era "descrita" e significada como participação. Se esta é afirmação de uma vontade ou expressão de valores e interesses em primeira pessoa do singular, a questão da legitimidade simplesmente não se coloca, pois o sujeito da vontade, valores ou interesses e a voz que os exprime são unos. Porém, se a atuação contempla falar em nome de outrem, configura-se curiosamente um paradoxo de legitimidade, pois, de um lado, as formas de representação extraparlamentar acusam implícita ou explicitamente limites na representação eleitoral, mas, de outro lado, não possuem mecanismos próprios claros ou aceitos capazes de alicerçarem sua própria legitimidade (Houtzager e Gurza Lavalle, 2010).

Via de regra, os atores das novas modalidades formais e informais de representação extraparlamentar carecem de autorização, ou seja, são exercidas por afinidade, de modo virtual, presuntivo (assumed), substitutivo (surrogate), autoassumido (self-authorized), em qualidade de mediadores políticos (mediated politics) e no exercício de práticas de representação não eleitorais (non-electoral political representation), como representação cidadã (citizen representatives) ou simplesmente advogando (advocacy) como representantes discursivos (discursive representatives) - para citar apenas alguns dos vocábulos de um repertório semântico recente e crescente, dedicado a apreender e conferir significado à pluralização da representação em curso $^{15}$. Em que pese

\footnotetext{
${ }^{15}$ Por "afinidade" conforme Avritzer (2007); "surrogated" conforme Mansbridge (2003); "advocacy" de acordo com Urbinati (2006a) ou Sorj (2005); "self-autorized" e "citizen representatives" conforme Urbinati e Warren (2007); "non-electoral political representation" no sentido de Castiglione e Warren (2006); "mediated politics" conforme Peruzzotti (2005); "presuntiva” como se define em Gurza Lavalle, Houtzager e Castello (2006b); e "virtual” conforme Gurza Lavalle, Houtzager e Castello (2006b).
} 
a dispersão do vocabulário, há um núcleo comum nesse elenco de formulações, pois cada uma articula ao seu modo a falta de autorização e, consequentemente, de mandato, com um ato ou opção unilateral de identificação do representante para com o representado. Por isso trata-se de uma representação que é presumida, animada pela afinidade, substituindo ou colocando-se no lugar daqueles que se decide autonomamente representar. Seja dito de passagem, com o intuito de reparar uma omissão surpreendentemente comum na literatura, a primeira formulação sistemática dessa combinação de elementos alheios à lógica da autorização, na história do pensamento sobre a representação política no governo representativo, se encontra na ideia de representação virtual de Edmund Burke (1942 [1774]), entendida como uma representação passível de ser reconhecida como tal pelos interesses representados, embora não mediada por ato de autorização.

128 Como equacionar, então, o paradoxo da legitimidade intrínseco a formas de representação não autorizadas? A autorização é uma questão de várias arestas e define um impasse não apenas pela sua ausência em si, mas pela dificuldade de remeter essas formas de representação a bases ou grupos sociais claros. Formas institucionalizadas de representação extraparlamentar podem contemplar modalidades de representação ex officio, isto é, prescritas por regimento ou cargo para desempenhar funções predefinidas. Quando um ator é indicado para se desempenhar como representante de interesses e segmentos específicos da população, como ocorre no caso de alguns conselhos gestores de políticas no Brasil, ele é autorizado legalmente. Contudo, a proliferação de expedientes de representação de interesses de grupos específicos da população mediante representantes ex officio é mais um signo dos tempos - da pluralização da representação - do que uma resposta satisfatória à questão da legitimidade. Obviamente, sequer cabe 
cogitar essa possibilidade para modalidades informais de representação. Ademais, a autorização pressupõe logicamente a definição do universo no qual se inscreve o grupo ou base social passível de ser representado (constituency). A representação eleitoral trabalha com bases territoriais de eleitores, mas no caso das modalidades de representação extraparlamentar nem sempre é claro qual o grupo social implicado, nem há modelos únicos que permitam dirimir quais grupos são ou deveriam ser representados pelos novos atores da representação. Mais: esses atores não raro ecoam as críticas clássicas dos partidários da representação proporcional aos efeitos da agregação territorial de preferências, atuando em nome de interesses difusos e/ou sub-representados porque distribuídos espacialmente de modo descontínuo - ambientalismo e direitos humanos, no primeiro caso, e preferência sexual, no segundo.

A incorporação da ideia de accountability tanto no debate sobre a pluralização da representação quanto no campo de estudos da sociedade civil constitui nitidamente um movimento no sentido de promover novas estratégias conceituais. Em outras palavras, frente à impossibilidade de resolver satisfatoriamente um modelo de autorização, a dimensão da accountability tem sido resgatada como uma via alternativa para elaborar a eventual legitimidade das novas práticas de representação (Alnoor e Weisband, 2007; Fox, 2006; Jordan, 2005; Castiglione e Warren, 2006; Avritzer, 2007; Gurza Lavalle e Isunza, 2010). De modo mais preciso, o deslocamento da autorização para a accountability torna a legitimidade dependente de um processo que se desdobra no tempo e não de um ato inicial de consentimento, uma vez que se o controle por parte dos eventuais beneficiários implica o conhecimento da representação presuntiva exercida em seu nome, a reiteração ou renovação do controle supõe reconhecimento, confere legitimidade e permite pensar em uma espécie de autorização implícita. 


\section{À guisa de conclusão}

Há mais de quarenta anos, no primeiro capítulo de seu trabalho seminal sobre o conceito de representação, Pitkin detectou a relação entre autorização e accountability como fonte de legitimidade, embora de modo crítico: as teorias centradas na ideia de accountability teriam surgido da inconformidade diante das teorias da autorização, procurando tornar mais exigente o conceito de representação, denunciando as insuficiências de um ato de consentimento único e introduzindo a necessidade de controles e sanções sobre os políticos. No fundo, o que está em jogo é o caráter periódico das eleições em intervalos regulares e as vantagens para os eleitores derivadas da renovação do consentimento, ou seja, o papel do tempo no governo representativo (Manin, 1997, p. 217). Os reparos de Pitkin obedeciam ao formalismo da solução avançada pelos críticos do modelo de autorização, todavia, a filósofa não 130 sustentava uma posição anti-institucional, mas uma compreensão multidimensional da representação, capaz de conciliar conteúdo, substância ou "essência" com regras, instituições ou "forma", pois, "sem institucionalização [...] o ideal da representação permaneceria um sonho vazio [...]" (Pitkin, 1967, p. 239). Na sua trajetória, em boa medida acompanhando o espírito crítico do seu tempo, Pitkin foi progressivamente associando a realização desse ideal à participação e denunciando a difícil relação entre democracia e representação.

Nas últimas duas décadas, a trajetória da crítica democrática cruzou-se de modo paradoxal com a trajetória intelectual da autora. A participação perdeu sua condição polar de crítica interna à democracia e sua plausibilidade "natural" como modelo alternativo à democracia liberal, com capacidade de atrair expectativas normativas de índole a mais variada. Em deslocamento similar, a representação democrática foi desvencilhada da sua identidade como o 
governo representativo, e não apenas ampliou os flancos da crítica democrática, mas passou a significar analiticamente parte relevante das experiências de inovação democrática no Brasil e pelo mundo afora. Embora essas experiências sejam incompreensíveis geneticamente sem o papel normativo da participação na crítica democrática, é no horizonte da pluralização da representação que se tornam inteligíveis suas características distintivas, novidade histórica e alcances, bem como das suas implicações mais importantes para a teoria democrática. Cabe ao desenvolvimento de teorias sensíveis às mudanças em curso explorar tanto o papel e valores da participação em contextos de representação extraparlamentar quanto as respostas que essas modalidades de representação podem oferecer perante os desafios de fundamentar sua legitimidade.

\section{Adrian Gurza Lavalle}

é professor do Departamento de Ciência Política da USP e pesquisador do CEM-Cebrap

\section{Ernesto Isunza Vera}

é pesquisador do Centro de Investigaciones y Estudios Superiores en Antropología Social (Ciesas).

\section{Referências Bibliográficas}

ABAL MEDINA, J. M. 1996. "El camino hacia la democracia posrepresentativa: reflexiones sobre la modernidad, la representación, los partidos políticos y la democracia”. PostData, n. 2, pp. 253-287.

. 2004. La muerte y la resurrección de la representación política. México: FCE.

ALBUQUERQUE, M. C. 2008. A participação da sociedade na redefinição de políticas de direitos: os direitos da infância e o direito a moradia em países do Cone Sul na virada para o século XXI. Tese de doutorado. São Paulo: Prolam-USP.

ACKERMAN ROSE, J. M. 2007. El instituto federal de acceso a la información pública: diseño, desempeño y sociedad civil. México: Centro de Investigaciones y Estudios Superiores en Antropología Social - Universidad Veracruzana. 
ALMEIDA, D. 2010. "Metamorfose da representação política: lições práticas dos conselhos de saúde no Brasil”. In: AVRITZER, L. (org.). A dinâmica da participação local no Brasil. São Paulo: Cortez.

ALNOOR, E.; WEISBAND, E. (coords.). 2007. Global accountabilities: participation, pluralism, and public ethics. Cambridge: Cambridge University Press.

ALONSO, J. R. 2007. Leyes de transparencia y acceso a la información gubernamental locales: la emergencia del derecho a la información. México: Centro de Investigaciones y Estudios Superiores en Antropología Social - Universidad Veracruzana.

ALONSO, J.; AZIZ, A. 2005. Campo electoral, espacios autónomos y redes: el consejo general del IFE (1996-2005). México: Centro de Investigaciones y Estudios Superiores en Antropología Social Universidad Veracruzana.

ANKERSMIT, F.R. 2002. Political representation. Stanford: Stanford University Press.

ANSELL, C.; GINGRICH, J. 2006. "Trends in decentralization”. In: CAIN, B. E.; DALTON, R. J.; SCARROW, S. E. (orgs.). Democracy transformed? Expanding political opportunities in advanced industrial democracies. Oxford: Oxford University Press.

132 ARAUJO, C. 2000. "República e democracia”. Lua Nova, n.51, pp. 5-30.

ARDITTI, B. 2005. "El devenir-otro de la política: un archipiélago postliberal". In: (org.). ¿Democracia post-liberal? El espacio político de las asociaciones. México: Anthropos/Unam.

AVRITZER, L. 2007. "Sociedade civil, instituições participativas e representação: da autorização à legitimidade da ação". Dados, v. 50, n. 3, pp. 443-464.

; WAMPLER, B. 2008. The Expansion of participatory budgeting in Brazil. Relatório de pesquisa elaborado para o Banco Mundial.

; NAVARRO, Z. 2003. A inovação democrática no Brasil: o orçamento participativo. São Paulo: Cortez.

AZIZ, A.; ISUNZA VERA, E. 2007. "La crisis del modelo electoral mexicano: financiamiento, medios, instituciones y política social”. Foro Internacional, v. 47, n. 4, pp. 740-784.

BACHELARD, G. 1972. La formación del espíritu científico. Buenos Aires: Siglo XXI Editores.

BARBER, B. R. 2003 [1984]. Strong democracy: participatory politics for a new age. Berkeley: University of California Press.

BARNES, M.; SKELCHE, C. 2007. "Local knowledge and local representation: discourses and designs in participatory governance". 
Disponível em <http:/ / cinefogoconference.pbworks.com/f/PN023_ Barnes-Skelcher.pdf $>$. Acesso em 25/09/2011.

BOHMAN, J.; REHG, W. 2002. Deliberative democracy: essays on reason and politics. Boston: MIT Press.

BURKE, E. 1942 [1774]. "Carta a los electores de Bristol”. In: Textos politicos. México: FCE.

CABANNES, Y. 2006. "Les budgets participatifs em Amérique Latine: de Porto Alegre à l'Amérique Centrale, em passant par la zone andine, tendances, défis et limites". Mouvements, n. 47/48, pp.128-138.

CASTIGLIONE, D.; WARREN, M. E. 2006. "Rethinking democratic representation: eight theoretical issues". Paper apresentado na conferência Rethinking Democratic Representation do Centre for the Study of Democratic Institutions. British Columbia: University of British Columbia. CHALMERS, D. A.; MARTIN, S. B.; PISTER, K. 1997. “Associative networks: new structures of representation for the popular sectors?". In: CHALMERS, D. A.; VILAS, C. M. The new politics of inequality in Latin America: rethinking participation and representation. Oxford: Oxford University Press.

CHAUDHRI, S.; HELLER, P. 2002. The plasticity of participation: evidence from a participatory governance experiment. Disponível em <http:/ / siteresources.worldbank.org/INTEMPOWERMENT/ Resources/13892_chaudhuri_heller.pdf > . Acesso em 25/09/2011.

CONTRERAS, M. A. 2003. "Cambios y discontinuidades del proceso de descentralización en el gobierno de Chávez”. Revista Venezolana de Economia y Ciencias Sociales, v. 9, n. 3, pp. 255-272.

CORNWALL, A. 2007. "Buzzwords and fuzzwords: deconstructing development discourse". Development in Practice, v. 17, n. 4-5, pp. 471-484. ; COELHO, V. S. 2007. "The politics of participation in new democratic arenas". In: (orgs.). Spaces for change? London: Zed Books.

CUNILL, G. N. 1997. Pensando lo público a través de la sociedad: nuevas formas de gestión pública e representación social. Caracas: Nueva Sociedad.

DAGNINO, E. 2002. "Sociedade civil, espaços públicos e a construção democrática no Brasil: limites e possibilidades". In: (org.). Sociedade civil e espaços públicos no Brasil. São Paulo: Paz e Terra. . 2004. "Sociedade civil, participação e cidadania: de que estamos falando?”. In: MATO, D. (coord.). Políticas de ciudadanía y sociedad civil en tiempos de globalización, Caracas: Faces/Universidad Central de Venezuela. 2006. "Sociedad civil, participación y ciudadanía: ¿de qué estamos hablando?”. In: ISUNZA VERA, E.; OLVERA, A. J. (coords.). 
Democratización, rendición de cuentas y sociedad civil: participación ciudadana y control social. México: Cámara de Diputados/ Miguel Ángel Porrúa/ Centro de Investigaciones y Estudios Superiores en Antropología Social - Universidad Veracruzana, pp. 223-242.

2007. "Citizenship: a perverse confluence". Development in Practice, v. 4, n. 17, pp. 549-556.

; OLVERA, A. J.; PANFICHI, A. (coords.). 2006. La disputa por la construcción de la democracia en América Latina. México: FCE/ Centro de Investigaciones y Estudios Superiores en Antropología Social Universidad Veracruzana.

DALTON, R. J.; GRAY, M. 2006. "Expanding the electoral marketplace". In: CAIN, B. E.; DALTON, R. J.; SCARROW, S. E. (orgs.). Democracy transformed? Expanding political oportunities in advanced industrial democracies. Oxford: Oxford University Press.

DELAMAZA, G. 2005. Tan lejos, tan cerca: políticas públicas y sociedad civil en Chile. Santiago de Chile: LOM.

DIAMOND, L.; MORLINO, L. 2005. Assessing the quality of democracy. Baltimore: Johns Hopkins University Press.

ELSTER, J. (org.). 1998. Deliberative democracy. Cambridge: Cambridge University Press.

134 FOX, J. 2006. "Sociedad civil y políticas de rendición de cuentas". Perfiles Latinoamericanos, n. 27, pp. 33-68.

FUNG, A. 2004. Empowered participation: reinventing urban democracy. Princeton: Princeton University Press. ; Wright, E. O. 2003. "Thinking about empowered participatory governance”. In: (orgs.). Deepening democracy: institutional innovation in empowered participatory governance. London: Verso.

GARSTEN, B. 2010. "Political representation and popular sovereignnity". In: SHAPIRO, I. et al. (orgs.). Political representation. Cambridge: Cambridge University Press.

GAVENTA, J. 2004 "Representation, community leadership and participation: citizen involvement in neighbourhood renewal and local governance". Disponível em <http:/ /www.dfid.gov.uk/r4d/PDF/ Outputs/CentreOnCitizenship/JGNRU.pdf > . Acesso em 25/09/2011. GRINDLE, M. S. 1999. Audacious reforms: institutional reform and democracy in Latin América. Baltimore/London: Johns Hopkins University Press.

GURZA LAVALLE, A. [No prelo]. "Participação: Valor, Utilidade, Efeitos e Causa”. In: PIRES, R. (org.). A efetividade das instituições participativas no Brasil: perspectivas, abordagens e estratégias de avaliação. Brasília: Ipea. 
; ACHARYA, A.; HOUTZAGER; P. 2005. "Beyond Comparative

Anecdotalism: Lesson on civil society and participation from São Paulo, Brazil". World Development,, v. 33, n. 6, pp. 40-48.

; CASTELLO, G. 2008. Sociedade civil, representação e a dupla face da accountability: Cidade do México e São Paulo. Caderno CRH, v. 21, pp. 67-86.

; ISUNZA VERA, E. 2010. "Precisiones conceptuales para el debate contemporáneo sobre la innovación democrática”. In:

La innovación democrática en América Latina: tramas y nudos de la representación, la participación y el control social. México: Centro de Investigaciones y Estudios Superiores en Antropología Social Universidad Veracruzana, p. 17-82.

; HOUTZAGER, P.; CASTELLO, G. 2005. "In whose name? Political representation and civil organizations in Brazil”. IDS Working Papers, v. 249, pp. 1-62.

\section{6a. "Democracia, pluralização da} representação e sociedade civil”. Lua Nova, n. 67, pp. 49-104. 2006b. "Representação política e organizações civis. novas instâncias de mediação e os desafios da legitimidade”. Revista Brasileira de Ciências Sociais, v. 21, n. 60, pp. 43-66. ; OLIVEIRA, O.; SERAFIM, L.; VOIGT, J. 2011. "Guarulhos as best case - mapping participatory governance structure and social conflicts". Relatório de pesquisa Chance 2 Sustain Project (manuscrito).

GUTMANN, A. 1995. "A desarmonia da democracia”. Lua Nova, n. 36, pp. 5-37. ; THOMPSON, D. 2004. Why deliberative democracy? Princeton: Princeton University Press.

HABERMAS, J. 1993. "La soberanía popular como procedimiento: un concepto normativo de lo público”. In: HERRERA, M. (coord.). Jürgen Habermas: moralidad, ética y política - propuestas y críticas. México: Alianza. 1995. "Três modelos normativos de democracia". Lua Nova, n. 36, pp. 39-53.

HELD, D. 1987. Models of democracy. Cambridge: Polity Press.

HELLER, P. 2001. "Moving the state: the politics of democratic decentralization in Kerala, South Africa, and Porto Alegre”. Politics and Society, v. 1, n. 29, pp. 131-163.

HEVIA DE LA JARA, F. 2006. "Participación ciudadana institucionalizada: análisis de los marcos legales de la participación en América Latina”. In: DAGNINO, E.; OLVERA, A. J.; PANFICHI, A. (coords.), La disputa por la construcción de la democracia en América Latina. México: Centro de Investigaciones y Estudios Superiores en Antropología Social Universidad Veracruzana. 
HIRST, P. 1994. Associative democracy: new forms of economic and social governance. Boston: MIT Press.

HORDIJIK, M. 2009. "Peru's participatory budgeting: configurations of power, opportunities for change”. The Open Urban Studies Journal, n. 2, pp. 43-55.

HOUTZAGER, P.; GURZA LAVALLE, A. 2010. "The paradox of civil society representation constructing new forms of democratic legitimacy in Brazil". In: TÖRNQUIST, O.; WEBSTER, N.; STOKKE, K. (orgs.). Rethinking popular representation. London: Sage. ; ___ JOSHI, A. (orgs.). 2008. State reform and social accountability: Brazil, India and México. IDS Bulletin, v. 38, n. 6.

IBGE. 2001. Indicadores dos municípios brasileiros.

ISUNZA VERA, E. 2006a. "Para analizar los procesos de democratización: interfaces socioestatales, proyectos políticos y rendición de cuentas”. In: ; OLVERA, A. J. (coords). Democratización, rendición de cuentas y sociedad civil: participación ciudadana y control social. México: Cámara de Diputados/ Miguel Ángel Porrúa/ Centro de Investigaciones y Estudios Superiores en Antropología Social - Universidad Veracruzana, pp. 265-291. 2006b. "Árbitros ciudadanos de las disputas partidarias. Una mirada sobre los consejos electorales federales en la contienda de 2000 en México”. In: _ _ OLVERA, A. J. (coords). Democratización, 136 rendición de cuentas y sociedad civil: participación ciudadana y control social. México: Cámara de Diputados/ Miguel Ángel Porrúa/ Centro de Investigaciones y Estudios Superiores en Antropología Social Universidad Veracruzana, pp. 545-569.

; GURZA LAVALLE, A. 2010. La innovación democrática en América

Latina: tramas y nudos de la representación, la participación y el control social. México: Centro de Investigaciones y Estudios Superiores en Antropología Social - Universidad Veracruzana.

JORDAN, L. 2005. "Nuevas formas de abordar la rendición de cuentas: derechos y contexto". In: ISUNZA VERA, E.; OLVERA, A. J. (coords). Democratización, rendición de cuentas y sociedad civil: participación ciudadana y control social. México: Cámara de Diputados/ Miguel Ángel Porrúa/ Centro de Investigaciones y Estudios Superiores en Antropología Social - Universidad Veracruzana.

LÜCHMANN, L. H. H. 2007. "A representação no interior das experiências de participação”. Lua Nova, n. 70, pp. 139-170. 2008. "Participação e representação nos conselhos gestores e no orçamento participativo”. Caderno CRH, v. 21, n. 52. pp. 87-97.

MACPHERSON, C. B. 1991 [1977]. La democracia liberal y su época. Madrid: Alianza Editorial. 
MANIN, B. 1997. The principles of representative government. Cambridge:

Cambridge University Press.

MANSBRIDGE, J. 2003. "Rethinking representation". American Political Science Review, n. 97, pp. 515-528.

MIGUEL, L. F. 2005. "Impasses da accountability: dilemas e alternativas da representação política”. Revista de Sociologia e Política, n. 25, pp. 25-38.

NOVARO, M. 1995. "O debate contemporâneo sobre a representação política”. Novos Estudos, n. 42, pp. 77-90.

2000. Representación y liderazgo en las democracias contemporáneas.

Rosario: Homo Sapiens.

OCHOA, M. 2004. "Ciudadanía perversa: divas, marginación y participación en la 'localización””. In: MATO, D. (coord.). Políticas de ciudadanía y sociedad civil en tiempos de globalización, Caracas: Faces/ Universidad Central de Venezuela.

OLIVEIRA, O. P. 2011. "Las dinámicas de transferencia del Presupuesto Participativo: una mirada hacia la acción de las elites”. In: WELP, Y.; WHITEHEAD, L. (org.). América Latina: caleidoscopio de la innovación democrática. México D. F.: Flacso.

OSTROM, E.; AHN, T.K.; OLIVARES, C. 2003. "Una perspectiva del capital social desde las ciencias sociales: capital social y acción colectiva”. Revista Mexicana de Sociología, ano 65, n. 1, pp. 155-233.

PATEMAN, C. 1992 [1970]. Participation and democratic theory. London: Cambridge University Press.

PERUZZOTTI, E. 2006. “Two approaches to representation”. Working paper. Departamento de Ciencias Sociales, Pontificia Universidad Católica del Perú.

; SMULOVITZ, C. (orgs.). 2002. Controlando la política: ciudadanos y medios en las nuevas democracias latinoamericanas. Buenos Aires: Temas. PETTIT, P. 2010. "Varieties of public representation". In: SHAPIRO, I. et al. (orgs.). Political representation. Cambridge: Cambridge University Press, pp. 61-88.

PHILLIPS, A. 2005. "Mobilizing representation 40 years after Pitkin". Paper apresentado no American Political Science Association Annual Meeting. Washington: APSA.

PIRES, R. (org.). [No prelo]. A efetividade das instituições participativas no Brasil: perspectivas, abordagens e estratégias de avaliação. Brasília: Ipea. PINTO, C. R. J. 2004. "Espaços deliberativos e a questão da representação". Revista Brasileira de Ciências Sociais, v. 19, n. 54, pp. 97-113.

PITKIN, H. F. 1967. The concept of representation. Berkeley: University of California Press. 
2004. "Representation and democracy: uneasy alliance".

Scandinavian Political Studies, v. 27, n. 3, pp. 335-342.

2006 [1989]. "Representação: palavras, instituições e ideias". Lua Nova, n. 67, pp. 15-47.

; SHUMER, S. M. 1982. “On participation”. Democracy, n. 2, pp. 43-54.

PLOTKE, D. 1997. "Representation is democracy". Constellations, v. 4, n. 1, pp. 19-34.

POGREBINSCHI, T. (coord.). 2010. Entre representação e participação: as conferências nacionais e o experimentalismo democrático brasileiro. Rio de Janeiro: Iuperj.

PRZEWORSKI, A. 2002. "Accountability social en América Latina y más allá”. In: PERUZZOTTI, E.; SMULOVITZ, C. Controlando la política: ciudadanos y medios den las nuevas democracias latinoamericanas. Buenos Aires: Temas.

; STOKES, S. C.; MANIN, B. 1999. Democracy, accountability and representation. Cambridge: Cambridge University Press.

PUTNAM, R. 2002. Comunidade e democracia: a experiência da Itália moderna. Rio de Janeiro: Ed. da FGV.

RAICHELIS, R. 2000. Esfera pública e conselhos de assistência social: caminhos da construção democrática. São Paulo: Cortez.

138 RIBEIRO, A. C. T.; GRAZIA, G. 2003. Experiências de orçamento participativo no Brasil: período de 1997 a 2000. Petrópolis: Vozes.

ROCHA, J. L. 2007. "Misión identitaria y mercadotecnia para permanecer: el Programa de Investigación de Nitlapán”. In: BEBBINGTON,

A. (org.). Investigación y cambio social: desafíos para las ONG en Centroamérica y México. Guatemala: Flacso.

ROSENSTONE, S.; HANSEN, J. M. 1993. Mobilization, participation, and democracy in America. New York: Longman.

ROSANVALLON, P. 1998. El pueblo inalcanzable. México: Instituto Mora.

SANTOS, B. S. 2002. "Democracia e Participação: o caso do Orçamento Participativo de Porto Alegre”. Pronto: Afrontamento.

SAWARD, M. 2010. The representative claim. Oxford: Oxford University Press. SCHEDLER, A. 1999. "Conceptualizing accountability". In:

DIAMOND, L.; PLATTNER, M. F. (orgs.). The self-restraining state: power and accountability in new democracies. Boulder/London: Lynne Rienner. ; DIAMOND, L.; PLATTNER, M. F. (orgs.). 1999. The self-restraining state: power and accountability in new democracies. Boulder/London: Lynne Rienner

SCHMITTER, P. 1974. "Still the century of corporatism?". Review of Politics, n. 36, pp. 85-131. 
SINTOMER, Y.; HERZBERG, C.; RÖCKE, A. (org.) . 2008. "Participatory budgeting in Europe: potentials and challenges". International Journal of Urban and Regional Research, v. 32, n.1, pp. 164-178.

SORJ, B. 2005. "Civil societies north-south relations: NGOs and dependency". Centro Edelstein de Pesquisas Sociais, working paper n. 1.

TATAGIBA, L. 2002. "Los consejos gestores y la democratización de las políticas públicas en Brasil”. In: DAGNINO, E. (org.). Sociedad civil, esfera pública y democratización en América Latina: Brasil. México: FCE, pp. 305-368. 2010. "Participação e reforma do Estado: sobre a arquitetura da participação em São Paulo”. In: O’DONNELL, G.; TULCHIN, J. S.; VARAS, A. (org.). New voices in the study of democracy in Latin America. Washington: Woodrow Wilson International Center for Scholars.

THOMPSON, L. (org.). 2007. Participatory governance? Citizens and the State in South Africa. Cape Town: African Centre for Citizenship and Democracy. TÖRNQUIST, O.; WEBSTER, N.; STOKKE, K. (orgs.). 2010. Rethinking popular representation. London: Sage.

URBINATI, N. 2000. "Representation as advocacy: a study of democratic deliberation”. In: Political Theory, v. 28, n. 6, pp. 758-786.

. 2006a. Representative democracy: principles and genealogy. Chicago:

University of Chicago Press.

. 2006b. “O que torna a representação democrática?". Lua Nova, n. 67, pp. 191-228.

; Warren, M. E. 2007. "The concept of representation in contemporary democratic theory". Annual Review of Political Science, v. 11, pp. 387-412.

VERBA, S.; NIE, N. H.; KIM, J-O. 1978. Participation and political equality: a seven-nation comparison. Cambridge/ New York: Cambridge University Press.

; SCHLOZMAN, K. L.; BRADY, H. E. 1995. Voice and equality: civic voluntarism in American politics. Cambridge/ London, UK: Havard University Press .

VIEIRA, M. B.; RUNCIMAN, D. 2008. Representation. Cambridge: Polity Press. WARREN, M. E. 2005. “Citizen Representatives”. Paper apresentado no American Political Science Association Annual Meeting. Washington: APSA. ; PEARSE, H. (orgs). 2008. Designing deliberative democracy: the british columbia citizens' assembly. New York: Cambridge University Press.

WILLIAMS, M. S. 1998. Voice, trust, and memory: marginalized groups and the failings of liberal representation. Princeton: Princeton University Press.

YOUNG, I. M. 2006 [2002]. "Representação política, identidade e minorias”. Lua Nova, n. 67, pp. 139-190. 